\title{
Seasonal range test run with Global Eta Framework
}

\author{
Dragan Latinović ${ }^{1}$, Sin Chan Chou ${ }^{1}$, and Miodrag Rančić ${ }^{2}$ \\ ${ }^{1}$ CPTEC/INPE, Cachoeira Paulista, 12630-000, SP, Brazil \\ ${ }^{2}$ NCEP, College Park, 20740, MD, USA
}

Correspondence to: Dragan Latinović (dragan.latinovic@cptec.inpe.br)

Received: 24 January 2017 - Revised: 15 May 2017 - Accepted: 12 June 2017 - Published: 20 July 2017

\begin{abstract}
Global Eta Framework (GEF) is a global atmospheric model developed in general curvilinear coordinates and capable of running on arbitrary rectangular quasi-uniform spherical grids, using stepwise ("Eta") representation of the terrain. In this study, the model is run on a cubed-sphere grid topology, in a version with uniform Jacobians (UJ), which provides "equal-area" grid cells, and a smooth transition of coordinate lines across the edges of the cubed-sphere. Within a project at the Brazilian Center for Weather Forecasts and Climate Studies (CPTEC), a nonhydrostatic version of this model is under development and will be applied for seasonal prediction studies. This note describes preliminary tests with the GEF on the UJ cubed-sphere in which model performance is evaluated in seasonal simulations at a horizontal resolution of approximately $25 \mathrm{~km}$, running in the hydrostatic mode. Comparison of these simulations with the ERA-Interim reanalyses shows that the $850 \mathrm{hPa}$ temperature is underestimated, while precipitation pattern is mostly underestimated in tropical continental regions and overestimated in tropical oceanic regions. Nevertheless, the model is still able to well capture the main seasonal climate characteristics. These results will be used as a control run in further tests with the nonhydrostatic version of the model.
\end{abstract}

1

\section{Introduction}

Global Eta Framework (GEF) is a global atmospheric model, based on general curvilinear coordinates and thus capable of running on various rectangular spherical grids, developed by Zhang and Rančić (2007). This model is chosen for a study with the objective to estimate the effects of higher-resolution treatment of convection on seasonal prediction skills. To this end, the GEF, operating in the cubed-sphere version, will be supplied with a nonhydrostatic option and run at very high resolutions in seasonal simulations. Sadourny (1972) suggested application of cubed-sphere, whose grid topology was promising a major increase of computational efficiency in the general circulation models of the atmosphere. The interest in application of cubed-sphere was renewed during the 1990s, with the advent of parallel computing, because the grid uniformity and the geometrical symmetry made this grid very attractive for application of parallel computing paradigm. In comparison, the standard longitude-latitude grid requires application of Fourier filtering around poles, which, on the massively parallel computers, degrades com- putational efficiency. A series of papers appeared, suggesting application and various improvements of the cubed-sphere: Rančić et al. (1996) and McGregor (1996) designed a conformal cubed-sphere; Ronchi et al. (1996) found a new way to use the original Sadourny's gnomonic cubed-sphere; Purser and Rančić (1998) suggested an improvement of the conformal cubed-sphere which was used in the first version of GEF in 2007. The current version of the model uses a further improvement that provides an "equal-area" cubed-sphere, without angular discontinuities across the edges of the cube (Purser and Rančić, 2011; Purser et al., 2014; Rančić et al., 2017) (Fig. 1).

The Brazilian Center for Weather Forecasts and Climate Studies (CPTEC) has been using a spectral global model (Bonatti, 1996) to provide weather and seasonal climate forecasts since the beginning of the center operational activities. The seasonal forecasts at CPTEC are currently produced by an ensemble of global atmospheric model (Cavalcanti et al., 2002), an ensemble of coupled ocean-atmosphere model (Siqueira and Nobre, 2006), and an ensemble of the regional Eta model (Chou et al., 2005). The high computational de- 

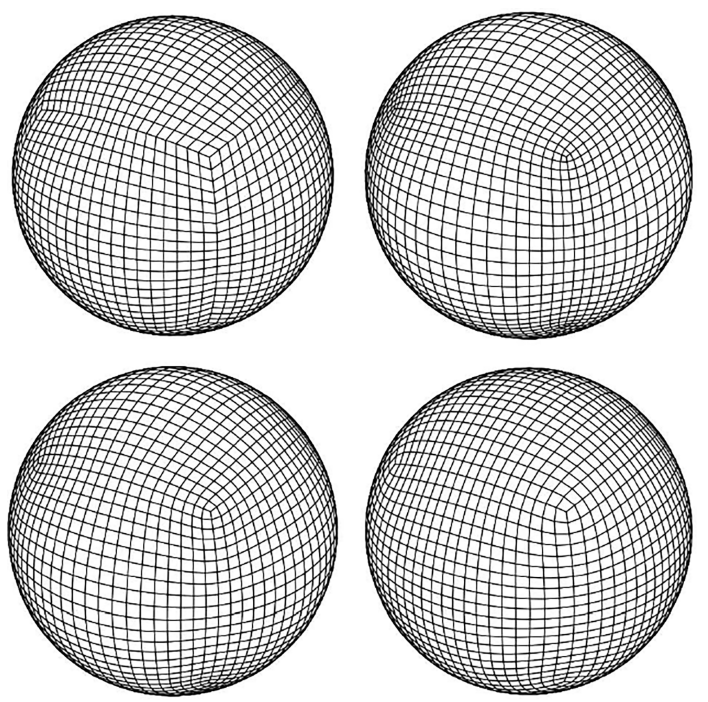

Figure 1. Cubed-spheres: (a) Upper left panel: gnomonic (Sadourny, 1972); (b) upper-right panel: conformal (Rančić et al., 1996); (c) lower-left panel: smooth (SM) (Purser and Rančić, 1998); (d) lower-right panel: UJ (Rančić et al., 2017).

mand of the spectral model for long-term simulations limits the CPTEC global models to the coarse resolution of about $200 \mathrm{~km}$. The GEF development at CPTEC for seasonal forecasts is a future, less computationally demanding alternative for the operational seasonal forecasts at the center.

The objective of this work is to evaluate the GEF model on the UJ cubed-sphere in seasonal range simulations at a $25 \mathrm{~km}$ horizontal resolution.

\section{Comparison of GEF with the regional Eta model}

GEF represents a globalization of the regional Eta model (Mesinger, 1974, 2000; Janjić, 1984, 1990, 1994; Mesinger et al., 1988, 2012; Mesinger and Lobocki, 1991; Black, 1994; Chen et al., 1997; Chou et al., 2000, 2002, 2005, 2012; Ek et al., 2003; Bustamante and Chou, 2009; Gomes and Chou, 2010; Pesquero et al., 2010; Doyle et al., 2013; de Andrade Campos et al., 2017; Lyra et al., 2017; Mesinger and Veljovic, 2017; Pilotto et al., 2017). The unique feature of the Eta model is a stepwise formulation of terrain, which was introduced with the idea to reduce the error of pressure gradient force of the sigma system in the presence of steep mountains, but turned out to offer many other advantages. For example, in one of recent tests (Mesinger and Veljovic, 2017), it is shown that in a situation of a major topographic impact, upper level trough crossing Rocky Mountains, the Eta model in ensemble experiments outperformed its ECMWF driver members to the extent that a number of times all 21 Eta ensemble members placed strongest $250 \mathrm{hPa}$ winds more accurately than their ECMWF driver members. A problem of flow separation in the lee of the bell-shaped topography, dis- (a)

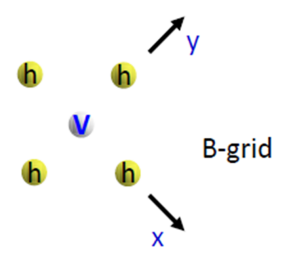

(b)

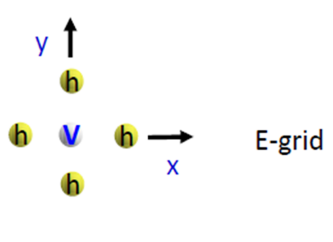

Figure 2. (a) Arakawa's B-grid in GEF, (b) Arakawa's E-grid in regional Eta model.

covered by Gallus Jr. and Klemp (2000), has been removed by a refinement of the eta discretization, referred to as "sloping steps" but in fact a simple version of a cut-cell scheme (Mesinger and Jović, 2002; Mesinger et al., 2012; Mesinger and Veljovic, 2017). The step-terrain approach is especially important in the case of areas where weather conditions are strongly affected by high mountains, such as the Andes in South America. Therefore, this is one of the reasons for choosing the Eta approach in this study. Being an efficient, global version of the regional Eta model, GEF seems appropriate for seasonal climate studies over this area. Although it is built upon the Eta model, GEF at present still does not employ sloping steps (Mesinger et al., 2012). Other differences in comparison with the regional Eta model are that GEF is reformulated in terms of general curvilinear coordinates and uses the Arakawa B-grid for distribution of variables (Arakawa and Lamb, 1977, Fig. 2), while the regional Eta model is designed in longitude-latitude grid and uses the E-grid.

\section{Preliminary results and discussion}

A preliminary evaluation reported in Latinović et al. (2013) verified model capability to simulate extreme climate events and stability in long-term, low-resolution $(\sim 230 \mathrm{~km})$ climate type runs. With a new, "equal-area" grid and increased resolution $(\sim 25 \mathrm{~km})$, continuous seasonal (90-day) runs were performed (Fig. 3).

The initial condition used was 00:00 UTC 9 February 1996. Figure 3 shows globally averaged $850 \mathrm{hPa}$ temperature, $850 \mathrm{hPa}$ wind and $200 \mathrm{hPa}$ wind from GEF simulation in comparison against ERA-Interim reanalyses (Dee et al., 2011). The time series of $850 \mathrm{hPa}$ temperature show that the global mean values are slightly underestimated when compared with reanalysis, although they follow the trend of seasonal increase/decrease, exactly like in the reanalysis. In addition, the simulated time series of $850 \mathrm{hPa}$ temperature shows a phase lag of a few days at the beginning of integration before it reaches the state of equilibrium and later it continues to vary around $1-2{ }^{\circ} \mathrm{C}$ lower than the reanalysis. The significant difference between GEF and ERA-Interim temperatures in at the beginning of the integration is probably a consequence of different discretization and vertical interpolations of temperature in GEF. The model uses geopotential 
(a)

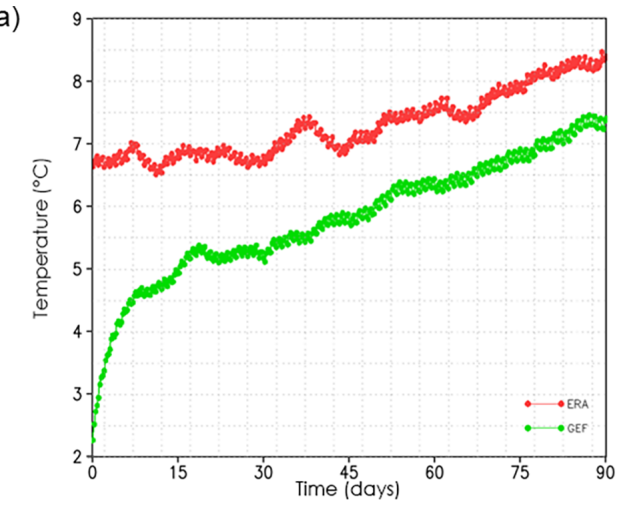

(b)

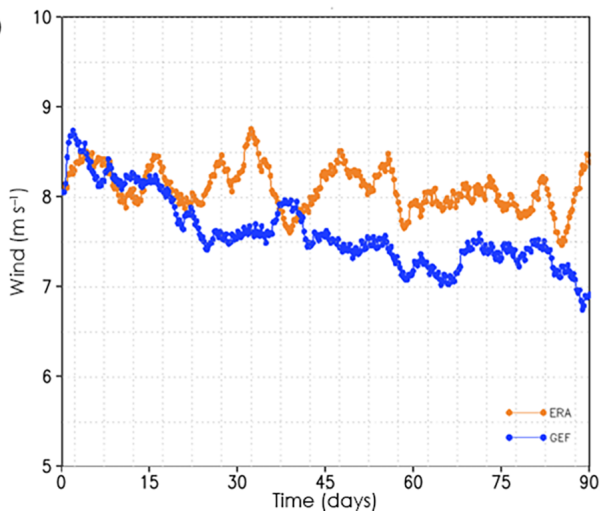

(c)

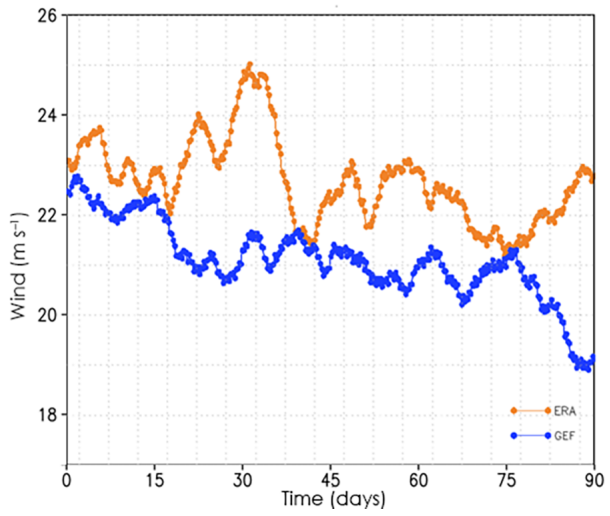

Figure 3. February to April (FMA) 1996 time series of global mean variables from ERA-Interim reanalyses and simulated by GEF: (a) $850 \mathrm{hPa}$ temperature $\left({ }^{\circ} \mathrm{C}\right.$ ) (the green curve is GEF and the red curve is the reanalysis) and (b) $850 \mathrm{hPa}$ wind $\left(\mathrm{m} \mathrm{s}^{-1}\right.$ ), and (c) $200 \mathrm{hPa}$ wind $\left(\mathrm{m} \mathrm{s}^{-1}\right)$ (the blue curves are GEF and the brown curves are the reanalyses).
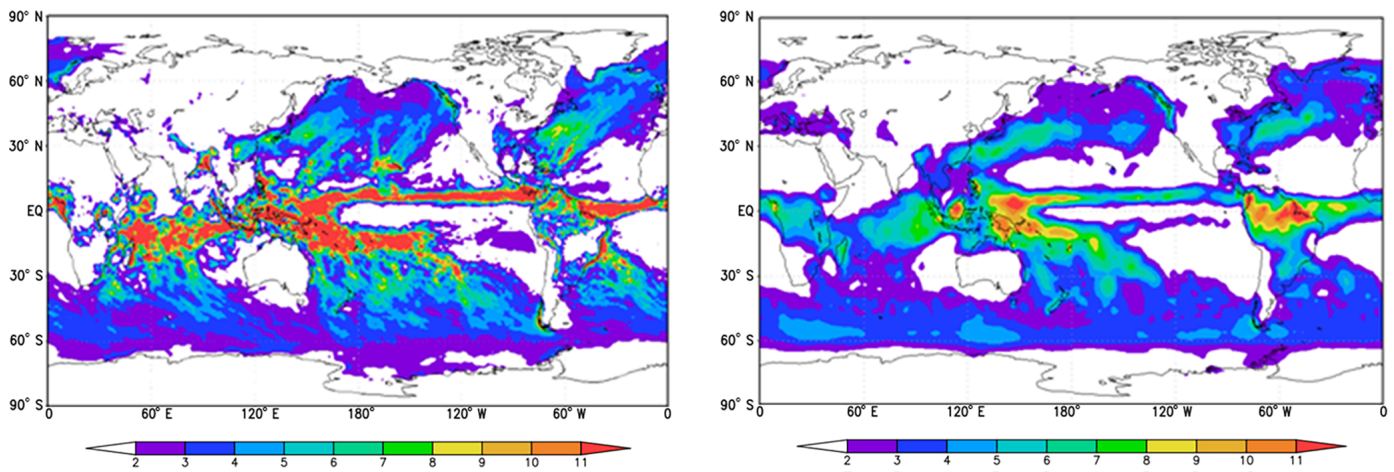

Figure 4. February to April (FMA) 1996 mean precipitation $\left(\mathrm{mm} \mathrm{day}^{-1}\right.$ ) from GEF (a) and GPCP (b).

height to calculate temperature and vertically interpolates it to the levels of the model. In the post-processing phase, another vertical interpolation is applied to the temperature from model levels to the standard pressure levels. Wind magnitude compares reasonably with the reanalysis both in the lower and upper troposphere. The $850 \mathrm{hPa}$ mean wind simulation follows approximately the reanalysis, but mostly underestimates and occasionally overestimates, especially at the beginning of integration, when the differences reach at most about $1.5 \mathrm{~m} \mathrm{~s}^{-1}$. In contrast, the simulated $200 \mathrm{hPa}$ mean wind shows underestimate by up to $4 \mathrm{~m} \mathrm{~s}^{-1}$. Figure 4 shows that the global pattern of the seasonal mean precipitation agrees relatively well with the observed precipitation from GPCP (Global Precipitation Climatology Project). However, model produces a significant overestimate, mostly in the tropical oceanic regions, and produces some underestimate in tropical continental regions, especially in parts of Africa 
and South America, where it fails to represent typical pattern of precipitation on each continent.

These results show the model ability to perform simulations at an increased horizontal resolution using an upgrade of the cubed-sphere, and demonstrate the model stability in the long-term, seasonal run. It is important to mention that this is the first seasonal run made with the GEF. Further adjustments in convective parameterization schemes are planned in order to improve precipitation simulation, but the main focus will be on inclusion of nonhydrostatic effects and the further increase of horizontal resolution.

\section{Conclusions and further plans}

Preliminary results show that GEF is capable of producing reasonable results over seasonal range running at high resolution. It is important to point out that all simulations were performed with relatively modest use of computational resources, 600 processor cores. We see these results as encouraging and it is expected that with the inclusion of the nonhydrostatic mode, GEF will improve on the seasonal predictions at higher horizontal resolution. The method of Janjić et al. (2001) and Janjić (2003) provides a useful approach to analyze the influence of nonhydrostatic processes, since it offers an easy way to switch the model from the hydrostatic to the nonhydrostatic option. Comparing the outputs of both hydrostatic and nonhydrostatic versions of the model, running at a horizontal resolution higher than $10 \mathrm{~km}$, it is expected to give insight in the contribution of the nonhydrostatic convective processes in the seasonal runs, especially in tropical regions.

Data availability. The model we used in this research (Global Eta Framework) will be available online very soon on our page: http: //etamodel.cptec.inpe.br/download/.

Competing interests. The authors declare that they have no conflict of interest.

Special issue statement. This article is part of the special issue "16th EMS Annual Meeting \& 11th European Conference on Applied Climatology (ECAC)". It is a result of the 16th EMS Annual Meeting \& 11th European Conference on Applied Climatology (ECAC), Trieste, Italy, 12-16 September 2016.

Acknowledgements. This work is supported by scholarships of the CAPES foundation of Ministry of Education in Brazil and the Brazilian National Council of Technological and Scientific Development (CNPq).

Edited by: Daniel Reinert

Reviewed by: two anonymous referees

\section{References}

Arakawa, A. and Lamb, V. R.: Computational design of the basic dynamical processes of the UCLA general circulation model, in: Methods of Computational Physics, 17, Academic Press, New York, 173-265, 1977.

Black, T. L.: The new NMC mesoscale Eta Model: Description and forecast examples, Weather Forecast., 9, 265-278, 1994.

Bonatti, J. P.: Modelo de Circulação Geral Atmosférico do CPTEC, Climanálise Edição Comemorativa de 10 anos, Instituto Nacional de Pesquisas Espaciais, http://climanalise. cptec.inpe.br/ rclimanl/boletim/cliesp10a/bonatti.html (last access: 17 July 2017), 1996.

Bustamante, J. F. F. and Chou, S. C.: Impact of including moisture perturbations on short-range ensemble forecasts, J. Geophys. Res., 114, D20112, https://doi.org/10.1029/2009JD012395, 2009.

Cavalcanti, I. F. A., Marengo, J. Á., Satyamurty, P., Nobre, C. A., Trosnikov, I., Bonatti, J. P., Manzi, A. O., Tarasova, T., Pezzi, L. P., D’Almeida, C., Sampaio, G., Castro, C. C., Sanches, M. B., and Camargo, H.: Global climatological features in a simulation using the CPTEC-COLA AGCM, J. Climate, 15, 29652988, 2002.

Chen, F., Janjić, Z., and Mitchell, K.: Impact of atmospheric surface-layer parameterizations in the new land-surface scheme of the NCEP mesoscale Eta Model, Bound.-Lay. Meteorol., 85, 391-421, 1997.

Chou, S. C., Bustamante, J. F., and Gomes, J. L.: Evaluation of Eta Model seasonal precipitation forecasts over South America, Nonlin. Processes Geophys., 12, 537-555, https://doi.org/10.5194/npg-12-537-2005, 2005.

Chou, S. C., Nunes, A. M. B., and Cavalcanti, I. F. A.: Extended range forecasts over South America using the regional Eta model, J. Geophys. Res., 105, 10147-10160, 2000.

Chou, S. C., Tanajura, C. A. S., Xue, Y., and Nobre, C. A.: Validation of the Coupled Eta/SSiB Model over South America, J. Geophys. Res., 107, 8088, https://doi.org/10.1029/2000JD000270, 2002.

Chou, S. C., Marengo, J. A., Lyra, A., Sueiro, G., Pesquero, J., Alves, L. M., Kay, G., Betts, R., Chagas, D., Gomes, J. L., Bustamante, J., and Tavares, P.: Downscaling of South America present climate driven by 4-member HadCM3 runs, Clim. Dynam., 38, 635-653, https://doi.org/10.1007/s00382-011-1002-8, 2012.

de Andrade Campos, D., Chou, S. C., Spyrou, C., Chagas, J. C. S., and Bottino, M. J.: Eta model simulations using two radiation schemes in clear-sky conditions, Meteorol. Atmos. Phys., https://doi.org/10.1007/s00703-017-0500-6, in press, 2017.

Dee, D. P., Uppala, S. M., Simmons, A. J., Berrisford, P., Poli, P., Kobayashi, S., Andrae, U., Balmaseda, M. A., Balsamo, G., Bauer, P., Bechtold, P., Beljaars, A. C. M., van de Berg, L., Bidlot, J., Bormann, N., Delsol, C., Dragani, R., Fuentes, M., Geer, A. J., Haimberger, L., Healy, S. B., Hersbach, H., Hólm, E. V., Isaksen, L., Kållberg, P., Köhler, M., Matricardi, M., McNally, A. P., Monge-Sanz, B. M., Morcrette, J.-J., Park, B.-K., Peubey, C., de Rosnay, P., Tavolato, C., Thépaut, J.-N., and Vitart, F.: The ERA-Interim reanalysis: configuration and performance of the data assimilation system, Q. J. Roy. Meteorol. Soc., 137, 553597, https://doi.org/10.1002/qj.828, 2011. 
Doyle, M. E., Tomasella, J., Rodriguez, D., and Chou, S.: Experiments using new initial soil moisture conditions and soil map in the Eta model over La Plata Basin, Meteorol. Atmos. Phys., 121, 119-136, https://doi.org/10.1007/s00703-013-0265-5, 2013.

Ek, M. B., Mitchell, K., Lin, Y., Rogers, E., Grunmann, P., Koren, V., Gayno, G., and Tarpley, J.: Implementation of NOAH land surface model advances in the NCEP operational mesoscale Eta model, J. Geophys. Res., 108, GCP 12-1-GCP 12-16, 2003.

Gallus Jr., W. A. and Klemp, J. B.: Behavior of flow over step orography, Mon. Weather Rev., 128, 1153-1164, 2000.

Gomes, J. L. and Chou, S. C.: Dependence of partitioning of model implicit and explicit precipitation on horizontal resolution, Meteorol. Atmos. Phys., 106, 1-18, https://doi.org/10.1007/s00703009-0050-7, 2010.

Janjić, Z.: Nonlinear advection schemes and energy cascade on semi-staggered grids, Mon. Weather Rev., 112, 1234-1245, 1984.

Janjić, Z.: The step-mountain coordinate: Physical package, Mon. Weather Rev., 118, 1429-1443, 1990.

Janjić, Z.: The step-mountain eta coordinate model: Further developments of the convection, viscous sublayer, and turbulence closure schemes, Mon. Weather Rev., 122, 927-945, 1994.

Janjić, Z.: A nonhydrostatic model based on a new approach, Meteorol. Atmos. Phys., 82, 271-301, 2003.

Janjić, Z., Gerrity, J., and Ničković, S.: An alternative approach to nonhydrostatic modeling, Mon. Weather Rev., 129, 1164-1178, 2001.

Latinović, D., Chou, S. C., and Nobre, P.: Capability of Global Eta Framework (GEF) to predict extreme climate events, in: Simpósio Internacional de Climatologia, 5. (SIC), Florianópolis, SC, Brazil, 2013.

Lyra, A., Tavares, P., Chou, S. C., Sueiro, G., Dereczynski, C. P., Sondermann, M., Silva, A., Marengo, J., and Giarolla, A.: Climate change projections over three metropolitan regions in Southeast Brazil using the non-hydrostatic Eta regional climate model at 5-km resolution, Theor. Appl. Climatol, https://doi.org/10.1007/s00704-017-2067-z, in press, 2017.

McGregor, L.: Semi-Lagrangian advection on conformal-cubic grids, Mon. Weather Rev., 124, 1311-1322, 1996.

Mesinger, F.: An economical explicit scheme which inherently prevents the false two-grid-interval wave in the forecast fields, in: Proc. Symp. "Difference and Spectral Methods for Atmosphere and Ocean Dynamics Problems", Part II, Academy of Sciences, Novosibirsk, 18-34, 1974.

Mesinger, F.: Numerical Methods: The Arakawa approach, horizontal grid, global, and limited-area modeling, in: General Circulation Model Development: Past, Present and Future, International Geophysics Series, Vol. 70, edited by: Randall, D. A., Academic Press, 373-419, 2000.

Mesinger, F. and Jović, D.: The Eta slope adjustment: Contender for an optimal steepening in a piecewise-linear advection scheme? Comparison tests, in: NOAA/NCEP Office Note 439, 29 pp., available at: http://www.emc.ncep.noaa.gov/officenotes/ index.shtml (last access: 17 July 2017), 2002.

Mesinger, F. and Lobocki, L.: Sensitivity to the parameterization of surface fluxes in NMC's eta model, in: 9th Conf. on Numerical Weather Prediction, Amer. Meteor. Soc., Denver, CO, 213-216, 1991.
Mesinger, F. and Veljovic, K.: Eta vs sigma: Review of past results, Gallus-Klemp test, and large-scale wind skill in ensemble experiments, Meteorol. Atmos. Phys, https://doi.org/10.1007/s00703016-0496-3, in press, 2017.

Mesinger, F., Janjić, Z., Ničković, S., Gavrilov, D., and Deaven, D. G.: The step-mountain coordinate: model description and performance for cases of Alpine lee cyclogenesis and for a case of an Appalachian redevelopment, Mon. Weather Rev., 116, 1493 1518, 1988.

Mesinger, F., Chou, S. C., Gomes, J. L., Jovic, D., Bastos, P., Bustamante, J. F., Lazic, L., Lyra, A. A., Morelli, S., Ristic, I., and Veljovic, K.: An upgraded version of the Eta model, Meteorol. Atmos. Phys., 116, 63-79, https://doi.org/10.1007/s00703-0120182-z, 2012.

Pesquero, J. F., Chou, S. C., Nobre, C. A., and Marengo, J. A.: Climate downscaling over South America for 1961-1970 using the Eta Model, Theor. Appl. Climatol., 99, 75-93, https://doi.org/10.1007/s00704-009-0123-z, 2010.

Pilotto, I. L., Rodríguez, D. A., Chou, S. C., Tomasella, J., Sampaio, G., and Gomes, J. L.: Effects of the surface heterogeneities on the local climate of a fragmented landscape in Amazonia using a tile approach in the Eta/Noah-MP model, Q. J. Roy. Meteorol. Soc., 143, 1565-1580, https://doi.org/10.1002/qj.3026, 2017.

Purser, R. J. and Rančić, M.: Smooth quasi-homogeneous gridding of the sphere, Q. J. Roy. Meteorol. Soc., 124, 637-647, 1998.

Purser, R. J. and Rančić, M.: A standardized procedure for the derivation of smooth and partially overset grids on the sphere, associated with polyhedra that admit regular griddings of their surfaces. Part I: Mathematical principles of classification and construction, NOAA/NCEP Office Note 460, 56 pp., available at: http://www.emc.ncep.noaa.gov/officenotes/ FullTOC.html (last access: 17 July 2017), 2011.

Purser, R. J., Rančić, M., Jović, D., and Latinović, D.: Two strategies for the mitigation of coordinate singularities of a spherical polyhedral grid, Presentation from 2014 PDEs workshop, Boulder, CO, USA, available at: http://www.cgd.ucar.edu/ events/pdes-workshop/Presentations-Posters/Purser.pdf (last access: 17 July 2017), 2014.

Rančić, M., Purser, R. J., and Mesinger, F.: A global shallow-water model using an expanded spherical cube: Gnomonic versus conformal coordinates, Q. J. Roy. Meteorol. Soc., 122, 959-982, 1996.

Rančić, M., Purser, R. J., Jović, D., Vasić, R., and Black, T.: A nonhydrostatic multiscale model on the uniform Jacobian cubedsphere, Mon. Weather Rev., https://doi.org/10.1175/MWR-D-160178.1, in press, 2017.

Ronchi, C., Iacono R., and Paolucci, R.: The "cubed sphere": a new method for the solution of partial differential equations in spherical geometry, J. Comput. Phys., 124, 93-114, 1996.

Sadourny, R.: Conservative finite-differencing approximations of the primitive equations on quasi-uniform spherical grids, Mon. Weather Rev., 22, 1107-1115, 1972.

Siqueira, L. and Nobre, P.: Tropical Atlantic sea surface temperature and heat flux simulations in a coupled GCM, Geophys. Res. Lett., L15708, https://doi.org/10.1029/2006GL026528, 2006.

Zhang, H. and Rančić, M.: A global Eta model on quasi-uniform grids, Q. J. Roy. Meteorol. Soc., 133, 517-528, 2007. 